\title{
Cytokine regulation of expression of class I MHC antigens
}

\author{
Aparna Raval, ${ }^{1}$ Niti Puri, ${ }^{1}$ P. C. Rath ${ }^{1}$ and \\ R. K. Saxena ${ }^{1,2}$ \\ 1 Immunology Laboratory, School of Life Sciences, \\ Jawaharlal Nehru University, New Delhi 110067, India \\ 2 Corresponding author \\ Accepted 12 January 1998
}

Abbreviation: MHC, major histocompatibility; IFN, interferon; TNF, tumor necrosis factor; LT, Iymphotoxin; NK, natural killer; MHC-AF, MHC class I augmenting factor; NF-RIF, natural killer-lysis resistance inducing factor; EC, embryonal carcinoma; CRE, class I regulatory element; ISGF-3, IFN stimulated gene facor-3; GAS, IFN- $\gamma$ activation site; GBP, guanylate binding protein; IRS, interferon response sequence; ICSBP, interferon consensus sequence binding protein; TAP, transporter associated with antigen presentation

\section{Introduction}

The major histocompatibility complex (MHC) is a chromosomal region that has been extensively characterized in several mammals, particularly man and mouse (Flavell et al., 1986 and Ploegh et al., 1981). The region which represents about $0.1 \%$ of the total genome in mouse, comprises a large number of genes classified into class I and class II MHC genes encoding a large number of polymorphic class I or class II MHC molecules respectively. Class I genes include HLA-A, B, C genes in man and $\mathrm{H}$ $2 \mathrm{D}, \mathrm{K}, \mathrm{L}$ in the mouse. Class II MHC genes include HLA$D R, D P, D Q$ in human and $H-2 I A$ and IE genes in the mouse. Class I MHC molecules are made of a highly polymorphic glycosylated transmembrane $\alpha$-chain of about $45 \mathrm{kDa}$, associated with a non-polymorphic, nonglycosylated, $12-\mathrm{kDa}$ chain, called $\beta_{2}$-microglobulin, not encoded within the $\mathrm{MHC}$ locus. Class II molecules encoded entirely within the MHC locus are made of two transmembrane polymorphic chains, $\alpha$ and $\beta$, which associate to form heterodimer. Class I heavy and light chains comprise three and one extracellular domains respectively, whereas both $\alpha$ and $\beta$ chains of class II molecules have two extracellular domains each. Both class I and class II $\mathrm{MHC}$ antigens show very high polymorphism and two of the extracellular domains, $\alpha_{1}$ and $\alpha_{2}$ in class I and $\alpha_{1}$ and $\beta_{1}$ in class II heterodimers display much more variability within different alleles than the other so called constant domains $\left(\alpha_{3}\right.$ and $\beta_{2}$ in class I and $\alpha_{2}$ and $\beta_{2}$ in class II molecules). Constant domains resemble immunoglobulin domain, which make MHC molecules members of the immunoglobulin super family (Williams et al., 1988).

Class I molecules are constitutively expressed on most types of nucleated cells. Class II molecules are expressed largely by cells of immune lineage, particularly B cells, macrophages, and dendritic cells. MHC class I molecules present antigenic peptides to $\mathrm{CD}^{+} \mathrm{T}$ cells. The majority of class I-binding peptides are derived from nuclear and cytosolic proteins. MHC class II molecules present peptides from antigens degraded by the endosomal/ lysosomal pathway to CD4+ T cells (Benham et al., 1995). Antigen receptor on T-cells (T-cell receptor or TCR) can recognize antigenic peptides only when the latter are presented associated with class I or class II MHC antigens. In addition, during T-cell differentiation, only those T-cells are permitted to develop which can recognize antigen associated with self MHC molecules, a phenomenon which is referred to as MHC restriction (Zinkernagel et al., 1979). While T-cells can only be activated in a MHC restricted manner, a class of non-T cytotoxic lymphocytes called natural killer (NK) cells, can spontaneously kill target cells in a MHC non-restricted manner. Levels of expression of class I MHC antigens on tumor cells however determine the susceptibility of tumor cells to NK cells (Haridas and Saxena, 1995a, 1995b, Saxena et al., 1996). Expression of class I MHC molecules thus play a crucial role in determining the susceptibility of target cells to both T cells and NK cells.

Keywords: cytokine regulation, MHC class I, expression

\section{Cytokines which modulate expression of MHC class I molecules}

\section{Interferons}

Interferons (IFN)- $\alpha$ and $\beta$ were originally described as anti-viral and anti-proliferative agents which were subsequently also shown to have immunoregulatory properties. IFN- $\alpha$ has successfully been used in the treatment of some leukemias, and to lesser extent renal cells carcinomas. Interferon- $\alpha$ and $\beta$ can antagonize the effects of IFN- $\gamma$ on $\mathrm{MHC}$ class II expression on murine macrophages and endothelial cells (Inaba et al., 1986).

IFN- $\gamma$ is produced by activated T cells and NK cells. Although IFN- $\gamma$ displays most of the biologic activities that have been ascribed to the other IFNs, it has 10-100 fold lower specific antiviral activity than either IFN- $\alpha$ or IFN- $\beta$. On the other hand IFN- $\gamma$ is $100-10,000$ times more active as an immunmodulator than are other classes of IFNs (Pace et al., 1985). Hence IFN- $\alpha$ or $\beta$ are primarily antiviral agents displaying some immunomodulatory activity, whereas IFN- $\gamma$ is primarily an immunomodulator 
but exerts some antiviral activity also (Trinchieri et al., 1985). Further more IFN- $\gamma$ synergizes with other mediators including lipopolysaccharide, tumor necrosis factor (TNF), granulocyte/macrophage-colony stimulating factor (GM-CSF), and immune complexes to augment the production of cytokines such as IL-1, which are themselves important in growth and differentiation of $\mathrm{T}$ and $B$ cells.

A single human IFN- $\gamma$ gene codes for a 166 amino acid polypeptide (Derynck et al. 1982), which after proteolytic cleavage gives rise to a mature positively charged polypeptide with a predicted molecular mass of $17 \mathrm{kDa}$. Two polypeptides self-associate to form a homodimer with an apparent molecular weight of $34 \mathrm{kDa}$ (Chang et al., 1984; Nagata et al., 1987). At physiologic concentrations little if any monomer is detectable. Only the dimer can display IFN- $\gamma$ biological activity, possibly because only it can effect IFN- $\gamma$ receptor dimerization (Fountoulakis et al., 1992). The IFN- $\gamma$ is highly sensitive to extremes of heat and $\mathrm{pH}$ and is denatured at temperatures above $56^{\circ} \mathrm{C}$ and $\mathrm{pH}$ values below 4.0 and above 9.0 (Mulkerrin et al., 1989).

The murine IFN- $\gamma$ gene encodes a mature 134 amino acid polypeptide with a predicted molecular mass of $15.4 \mathrm{kDa}$ (Gray et al., 1983). Like its human counterpart, murine IFN- $\gamma$ exists exclusively as a non covalently linked homodimer. Due to a low level of sequence homology, human and murine IFN- $\gamma$ display a strict species specificity in their ability to bind to and activate human and murine cells respectively. The individual human and murine polypeptides are differentially glycosylated, thereby giving rise to subunits of differing molecular weights, accounting for the observed molecular weight heterogeneity (range from 30-50 kDa) in fully mature homodimeric human and murine IFN- $\gamma$ molecules (Kelker et al., 1983, 1984). Glycosylation seems to be unimportant for biological activity of the molecule but might influence the dynamics of tissue distribution and circulatory half life of the molecule (Kelker et al., 1983).

IFN- $\gamma$ is produced by NK cells and certain subpopulation of T lymphocytes, namely TH1 subclass of CD4 ${ }^{+}$lymphocytes and certain $\mathrm{CD}^{+}$lymphocytes on activation by antigens or mitogens (Fong et al., 1990). In the human system, T cells that express the activation-dependent CD30 membrane antigen are the principal subset producing IFN- $\gamma$ (Alzona et al., 1994). Recently production of IFN- $\gamma$ by mononuclear phagocytes has also been described (Fultz et al., 1995).

All three types of INF enhance the expression of class I MHC antigens on a number of immunologically important cell types including mononuclear phagocytes, epidermal cells, endothelial cells, B lymphoid cells and macrophages (King et al., 1983; Trinchieri et al., 1985; Chang et al., 1994) IFN- $\gamma$ is somewhat more efficient in bringing about this effect. Cells with enhanced $\mathrm{MHC}$ I expression may become better targets for CTLs recognizing viral, tumor or autoantigens present in such cells. Following IFN treatment, the increase of HLA class I antigens on human cells is rapid (detectable after one hour), stable for at least $24 \mathrm{~h}$ and ranges from 2 to 10 times the initial levels (Rosa et al., 1986). Northern blot analysis of mRNA encoding HLA class I heavy chain has shown that IFN treatment increases the steady state level of mRNA for HLA-A, -B, -C in every cell type studied (Fellous et al., 1992). IFN- $\gamma$ could induce de novo expression of class I MHC antigen in K562 human erythroleukemia cells which have no basal expression of these antigens (Rosa et al., 1984). IFN thus appears to be both a modulator, as well as an inducer of MHC genes.

\section{Tumor necrosis factor and lymphotoxin}

Tumor necrosis factor- $\alpha$ (TNF- $\alpha$ ) is a 20-25 kDa protein which is produced by activated monocytes, $T$ cells and NK cells. TNF- $\alpha$ has a single copy gene which encodes a precursor product of 233 amino acids and a mature product of 157 amino acids after leader sequence is removed. The molecular weight of human recombinant TNF- $\alpha$ is $45 \mathrm{kDa}$ by gel filtration and $17 \mathrm{kDa}$ by SDSPAGE. Human and mouse TNF show $80 \%$ homology at amino acid level (Old 1985; Pennica et al., 1985). As a result, TNF- $\alpha$ lacks species specificity in its action (Batten et al., 1996).

Recombinant human TNF- $\alpha$ increases mRNA levels and surface expression of HLA-A, B antigens in normal (untransformed) human vascular endothelial cells and fibroblasts in vitro. This effect plateaues in several days and is sustained in presence of TNF. TNF- $\alpha$ has also been shown to upregulate constitutively expressed HLA genes in different tumor cell lines (Pfizenmaier et al., 1987) and several neoplastic cell lines of carcinoma and leukemia origin (Scheurich et al., 1986). TNF- $\alpha$ by itself is unable to induce de novo expression of HLA-A, B, C genes but acts as an enhancer of constitutive or IFN- $\gamma$ induced HLA gene expression. The expression of a critical density of class I MHC antigens on tumor cells is a prerequisite for tumor-specific immune responses and tumor rejection in immunocompetent hosts (Hui et al., 1984; Wallich et al., 1985). Enhancement of HLA expression upon combined treatment with IFN- $\gamma$ and TNF- $\alpha$ may result in a potentiation of the immunogenecity of a tumor. This appears to be of particular importance for those tumor cells expressing little or no HLA antigens and thus are resistant to direct cytotoxic actions of cytotoxic $T$ lymphocytes.

Lymphotoxin (LT) or TNF- $\alpha$ was described as a cytotoxic factor produced by activated T lymphocytes (Paul et al., 1988). Both murine and human LT genes are tightly linked to genes for TNF- $\alpha$ in the MHC locus. Murine LT is a mature protein of 169 amino acids and human LT a 171 amino acid long mature protein. Both have glycosylation 
sites. LT has a molecular weight of $60-70 \mathrm{kDa}$ by gel filtration and 20-25 kDa by SDS-PAGE and a pl of 5.8. The $25 \mathrm{kDa}$ form is the monomeric glycosylated form of LT which aggregates to produce the higher molecular weight forms. In vitro transcribed and translated murine lymphotoxin cDNA produces two sizes of LT on SDSPAGE gel of 18 and $34 \mathrm{kDa}$ (Li et al., 1987), representing monomeric and dimeric non-glycosylated LT. There is a remarkable homology ( $74 \%$ ) between amino acid sequences of murine (Li et al., 1987) and human (Nedwin et al., 1985) LT, explaining the lack of species specificity in their biological effects.

Both TNF- $\alpha$ and LT cause necrosis of a transplantable methyl cholanthrene-induced sarcoma in mice. The mechanism of this tumor necrosis does not appear to be due solely to direct killing because the Meth A sarcoma is not particularly LT-susceptible in vitro. Other effects of LT including increased expression of MHC antigens and subsequent cytotoxic $T$ lymphocyte attack may be responsible for this sarcoma necrosis (Paul et al., 1988). Human endothelial cells (HEC) are not killed by LT but their class I MHC expression increases on treatment with LT (Pober et al., 1987).

\section{MHC class I augmenting factor (MHC-AF)}

Previous work from our laboratory described a potential novel cytokine termed natural killer-lysis resistanceinducing factor (NK-RIF) which is detected in the culture supernatants of mitogen activated rat spleen cells (Saxena 1987, 1992). The factor was so named because it induced resistance to NK cell-mediated lysis of YAC tumor cells, which are otherwise highly susceptible to NK cells. NK-RIF treated YAC tumor cells expressed markedly enhanced levels of class I MHC antigens as compared to control YAC cells (Saxena et al., 1988). These results are consistent with the idea of an inverse correlation between NK susceptibility and class I MHC antigen expression on target tumor cells as discussed above. This NK-lysis resistance inducing factor (LRIF) has a molecular weight of 12.6 $\mathrm{kDa}$ and an isoelectric $\mathrm{pH}$ of 4.9 , is heat labile, and is deactivated by proteolytic enzymes (Saxena et al., 1988). Because NK-LRIF preparations purified by isoelectric focusing were devoid of any IL-2 or IFN activity, the factor is distinct from these cytokines.

NK-LRIF activity has also been isolated from culture supernatants of activated human peripheral blood mononuclear cells (Saxena et al., 1996; Raval et al., 1997) or mouse spleen cells (Sarin et al., 1995). While looking for the human or mouse equivalent of the rat NK-RIF, MHC class I augmentation was used as a primary bioassay and therefore, it is now referred to as MHC-augmenting factor (MHC-AF). In these studies an approach similar to that used for the purification of rat NK-RIF was utilized, only difference being the standardization of use of serumfree medium for the gerneration of human MHC-AF, to simplify the purification of this activity (Raval et al., 1997). The molecular weight of human MHC-AF was around $35 \mathrm{kDa}$ with a pl of 6.0 (Saxena et al., 1996). The activity was found to be susceptible to heat and proteolytic enzyme treatments (Raval et al., 1997). Mouse NK-RIF has a molecular weight of about $10 \mathrm{kDa}$ and a pl around 6.0 (Saxena et al., 1992).

Several lines of experimental evidence indicate that MHC-AF is distinct from IFN. Table 1 shows a comparison of MHC-AF and IFN- $\gamma$. (a) IFN activity is a molecular entity of about $50 \mathrm{kDa}$ (Saxena et al., 1992), rat NK-RIF, on the other hand, has an apparent molecular weight of 12.6 kDa (Saxena et al., 1988), (b) MHC-AF preparations lack detectable antiviral activity associated with IFN. The

Table 1. Comparison of properties of MHC-AF, IFN- $\gamma$ and TNF- $\alpha$

\begin{tabular}{llll}
\hline Property & MHC-AF & IFN- $\gamma$ & TNF- $\alpha$ \\
\hline Molecular weight on Sephadex G100 & $10-35 \mathrm{kDa}$ & $30-55 \mathrm{kDa}$ & $45 \mathrm{kDa}$ \\
Susceptibility to pH-2.0 treatment & No & Yes & n.d. \\
Antiviral activity in VSV/L929 assay & Absent & Present & Absent \\
Potency in terms of augmentation of MHC I on tumor cell lines & High & Relatively lower & Very low \\
Ability to induce de novo synthesis of MHC I (e.g. in K562) & Yes & Yes & No \\
Blocking of activity by anti- IFN- $\gamma$ antibodies & No & Yes & No \\
Blocking of activity by anti-TNF- $\alpha$ antibodies & No & No & Yes \\
Retention of activity on anti- IFN- $\gamma$ affinity column & No & Yes & No \\
Augmentation of class II MHC antigens & No & Yes & No \\
Augmentation of adhesion molecules (ICAM-1) & No & Yes & n.d. \\
Susceptibility to Trifluoroacetic acid (Reverse phase HPLC) & No & Yes & n.d. \\
Species specificity & No & Yes & No \\
Requirement of glycosylation for activity & Yes & No & No \\
\hline
\end{tabular}

n.d.: not determined. 
purification protocol for all MHC-AFs involves a step of $\mathrm{pH}-2.0$ dialysis for 2 days. By being acid stable, MHC-AF is quite distinct from IFN- $\gamma$, (c) the extent of enhancement in $\mathrm{MHC}$ I antigen expression of MHC-AF preparations cannot be explained by the presence of small amounts of contaminating IFN- $\gamma$ in these preparations, (d) the antiIFN antisera could not block the effects of MHC-AF on YAC cells, and (e) IFN- $\gamma$ induces the expression of both class I and class II MHC antigens whereas MHC-AF enhances the expression of class I MHC antigens only (Raval, 1997). MHC-AF does not act through IFN because it does not induce the production of IFN (Puri and Saxena,
1997). Neutralizing antibodies to TNF- $\alpha$ and IFN- $\gamma$ or $\beta$, had no effect on class I MHC augmenting activity of human MHC-AF preparations. In addition, an affinity column with immobilized monoclonal antibodies to IFN- $\gamma$ with proven efficacy to absorb IFN- $\gamma$, did not show any significant absorption of MHC-AF activity (Saxena et al., 1996).

Besides YAC cells, rat MHC-AF was found to induce increased levels of class I MHC antigen expression in a variety of other tumor cell lines, including EL4 lymphoma, L929 fibroblast cell line, methylcholanthrene-induced adenocarcinomas (MCA102 and MCA105), and melanoma (BL6) cell lines (Saxena et al., 1992). Human MHC-AF

Table 2. Transcription factors involved in Class I MHC gene in mammalian cells.

\begin{tabular}{|c|c|c|c|}
\hline $\begin{array}{l}\text { Trans- } \\
\text { acting } \\
\text { factor }\end{array}$ & Presence & Function & Reference \\
\hline H-2IIBP & $\begin{array}{l}\text { Induced by retinoic acid in } \\
\text { undifferentiated embryonic } \\
\text { carcinoma cells. }\end{array}$ & $\begin{array}{l}\text { Developmemtal regulation of class } \\
\text { I MHC gene. }\end{array}$ & Nagala et al., 1992 \\
\hline CREB & $\begin{array}{l}\text { Constitutive in cyclic AMP and } \\
\text { Calcium responsive cells and } \\
\text { tissues. }\end{array}$ & $\begin{array}{l}\text { Developmental regulation of class } \\
\text { MHC gene. }\end{array}$ & $\begin{array}{l}\text { Israel et al., } 1989 \\
\text { Roesler et al., } 1988\end{array}$ \\
\hline KBF1 & $\begin{array}{l}\text { Constitutively present in cells } \\
\text { and tissues expressing } \mathrm{MHC} \mathrm{I.}\end{array}$ & $\begin{array}{l}\text { Developmental and tissue specific } \\
\text { regulation of class I MHC gene. }\end{array}$ & $\begin{array}{l}\text { Israel et al., } 1987 \\
\text { Kimura et al., } 1986\end{array}$ \\
\hline H2TF1 & $\begin{array}{l}\text { Constitutively present in cells and } \\
\text { tissues expressing } \mathrm{MHC} \text { I. }\end{array}$ & $\begin{array}{l}\text { Developmental and tissue specific } \\
\text { regulation of class I MHC gene. }\end{array}$ & $\begin{array}{l}\text { Baldwin et al., } 1988 \\
\text { Kimura et al., } 1986\end{array}$ \\
\hline$N F-\kappa B$ & $\begin{array}{l}\text { Preexisting in inactive form in } \\
\text { association with I } \mathrm{\kappa} B \text { in many } \\
\text { cells and needs to be activated } \\
\text { by certain agents through } \\
\text { phosphorylation of } I \kappa B \text {. }\end{array}$ & $\begin{array}{l}\text { Developmental regulation of class I } \\
\text { MHC gene. It also participates } \\
\text { in the indution of class I MHC } \\
\text { gene by TNF- } \alpha \text {. }\end{array}$ & $\begin{array}{l}\text { Baldwin et al., } 1988 \\
\text { Israel et al., } 1989\end{array}$ \\
\hline ISGF-3 $\gamma$ & $\begin{array}{l}\text { Preexisting in IFN responsive cells. } \\
\text { Forms ISGF-3 complex with } \\
\text { ISGF- } 3 \gamma \text { in response to type I IFN } \\
\text { and acts as DNA binding factor. }\end{array}$ & Involved in JAK-STAT pathway. & Kessler et al., 1990 \\
\hline IRF-1 & $\begin{array}{l}\text { Present in basal levels and further } \\
\text { inducible in many cell types by } \\
\text { certain agents. }\end{array}$ & $\begin{array}{l}\text { Acts as a positive regulatory factor } \\
\text { in response to both type I and type } \\
\text { II IFN. }\end{array}$ & Miyamoto et al., 1988 \\
\hline IRF-2 & $\begin{array}{l}\text { Present in basal levels and further } \\
\text { inducible in many cell types by } \\
\text { certain agents. }\end{array}$ & $\begin{array}{l}\text { Repressor for IRF-1 mediated } \\
\text { activation of gene expression. }\end{array}$ & Harada et al., 1989 \\
\hline IRF-3 & $\begin{array}{l}\text { Constitutively present in a variety } \\
\text { of tissues but steady state mRNA } \\
\text { levels not increased by either IFN } \\
\text { or virus treatment of cells. }\end{array}$ & $\begin{array}{l}\text { Binds to ISRE, may associate } \\
\text { with other transcription factor(s) } \\
\text { to form complex. }\end{array}$ & Au et al., 1995 \\
\hline ICSBP & $\begin{array}{l}\text { Constitutively present in macro- } \\
\text {-phage and B cells and can be } \\
\text { induced in Tcells by IFN- } \gamma \text {. }\end{array}$ & $\begin{array}{l}\text { Act as a repressor of class I MHC } \\
\text { antigen. This repression can be } \\
\text { attenuated by IFN- } \gamma \text {. }\end{array}$ & Shirayoshi et al., 1988 \\
\hline
\end{tabular}


could enhance the class I MHC expression on Molt- 4 (human T cell leukemia) and HR-7 (human gastric carcinoma) tumor cells (Saxena et al., 1992) and could induce a marked dose dependent expression of $\mathrm{MHC}$ I antigens on human erythromyeloid leukemia cell line K562, which otherwise does not express HLA antigens (Sarin et al., 1995). This is a property which TNF lacks (Pfizenmaier et al., 1987). Table 2 further highlights the differences between MHC-AF and TNF. Mouse MHC-AF, like the rat counterpart, enhances the expression of class I MHC antigens on YAC tumor cells and renders them resistant to NK lysis (Sarin et al., 1995; Puri and Saxena, 1997). Mouse MHC-AF also enhances the class I MHC expression on EL4 and BW5147 (both murine T cell lymphomas) tumor cell lines but had no effect on class I MHC expression of K562 or HR-7 (both human tumor cell lines) cells (Puri et al., 1997). Human MHC-AF on the other hand, could enhance the class I MHC expression on murine EL4 and BW5147 tumor cell lines also. In this respect MHC-AF is quite different from IFN- $\gamma$ which is highly species specific. The class I MHC antigen expression on tumor cells in vivo is an important factor in determining the susceptibility of these cells to immunesurveillance mechanisms. In this context, MHC-AF which is a potent inducer of class I MHC antigen expression in vitro, has a potential for tumor class I MHC expression augmentation in vivo.

\section{Regulation of MHC gene expression}

The regulation of $\mathrm{MHC}$ gene expression plays a fundamental role in the homeostasis of the immune response. Tissue specific expression of class I and class II genes is developmentally regulated and is principally controlled at the level of transcription. In cells of the central nervous system that do not express class I genes, the crucial promoter/regulatory sequences of class I and $\beta_{2}$-microglobulin genes are largely unoccupied in vivo although factors that bind to the regulatory regions are present in the nuclear extracts of the cells (Burke et al., 1989). This suggests the existence of mechanisms that determines accessibility of regulatory nuclear binding factors to relevant cis-acting elements during development.

The expression of MHC gene products can also be regulated at the posttranscriptional level. It is reported that the $3^{\prime}$ untranslated region of HLA-DR mRNA interacts with at least two compartmentalized proteins, which seem to participate in mRNA partitioning in the nucleus and in the cytoplasm, respectively. Transfection of cDNA from the crucial $3^{\prime}$ untranslated region results in an mRNA that is preferentially released in the cytoplasm, where it mainly associates with ribosomes (Accolla et al., 1995). Thus, recognition of retention signals by distinct proteins may play a role in the distribution of $\mathrm{MHC}$ mRNA and, therefore, in the amount of mRNA translated within a cell.

Down regulation of $\mathrm{MHC}$ genes may be a mechanism by which pathogens escape from immune attack. The Tat gene of human immunodeficiency virus (HIV) can generate two forms of the Tat protein, one-exon Tat and two-exon Tat. One exon tat protein suppresses $\mathrm{MHC}$ class I expression by up to $50 \%$ by acting at the level of the class I gene promoter (Accolla et al., 1995). The rapid progression towards oncogenic transformation of cells infected with adenovirus 12 is associated with highly reduced class I expression. This is not due to a reduction in the amount of class I mRNA but, is a consequence of the very low level of TAP-1 (transporters associated with antigen presentation-1, tenfold less) and TAP-2 (100-fold less) mRNA, which results in a lower transport of $\mathrm{MHC}$ class I heterodimers to the cell surface (Proffit et al., 1994). Suppression of peptide transporter genes might be an important mechanism by which virus-transformed cells escape immune recognition in vivo.

\section{Assembly of MHC class I molecule}

MHC class I molecules present antigenic peptides to cytotoxic T cells. The expression of peptide loaded class I MHC molecule at the cell surface takes place in three steps. First, there is degradation of cellular proteins (or viral proteins in case of virus infected cells) to peptides in the cytosol, followed by active translocation of these peptides across the endoplasmic reticulum membrane and then the assembly of MHC class I heterodimers and their transport to the cell surface (Lehner et al., 1996). Peptide pool present in endoplasmic reticulum is crucial for the assembly of class I molecule since in absence of peptides occupying the groove on $\alpha_{1}-\alpha_{2}$ domains of the alpha chain of class I MHC antigen, proper assembly of class I MHC molecule does not take place.

Proteasome, a $700 \mathrm{kDa}$ complex present in the cytoplasm and nucleus of all cell types, is involved in nonlysosomal protein degradation of cytosolic proteins (Fehling et al., 1994; Rock et al., 1994; Van et al., 1994). The proteasome efficiently cleaves proteins at basic and hydrophobic residues. This facilitates the production of peptides with carboxy termini suitable for binding to class I MHC groove. Transportation of peptides generated in cytoplasm, to endoplasmic reticulum is carried by TAP-1 and TAP-2 proteins present on endoplasmic reticulum membrane (Monaco et al., 1990; Spies et al., 1990; Neefjes et al., 1993; Wang et al., 1996). Both TAP-1 and TAP-2 are multimembrane spanning proteins with an ATP-binding cassette. They can transport peptides across endoplasmic reticulum membrane in an energy depen-dent manner.

The peptide transporters are selective for peptide length and for the carboxy-terminal amino acid (Momburg et al., 1994; Schumacher et al., 1994). TAP has the highest 
affinity for peptides of 8-13 amino acids in length, which is the approximate size of MHC class I peptides. Within the endoplasmic reticulum lumen, assembly of the three components of class I MHC molecule i.e. the $\alpha$-chain, the $\beta_{2}$-microglobulin and the peptide that occupy the groove on the alpha chain, takes place. This process requires the participation of several chaperone proteins of which calnexin, calreticulin and tapasin are the most well studied ones. Calnexin transiently associates with the nascent heavy chain and plays an important role in the assembly process (Hochstenbach et al., 1992). It mediates disulfide bond formation and promote dimerization of $\alpha$ chain of class I MHC molecules with $\beta_{2}$-microglobulin. Calreticulin plays a key role in the association of class I molecule with TAP (Sadasivan et al., 1996). Tapasin, on the other hand, functions as a bridge connecting class I molecule and TAP (Kovacsovics et al., 1994; Sadasivan et al., 1996).

\section{Basal expression of class I MHC antigen}

The MHC class I molecule is broadly expressed on a variety of different cell types of mammals but its constitutive level varies markedly between cell types and tissues (David-Watine et al., 1990). The highest level of cell surface expression of class I MHC antigens occurs in lymphoid tissues. Whereas lower levels are found in other somatic tissues, such as kidney and liver. There is no detectable cell surface class I MHC expression on brain cells, germline cells and undifferentiated embryonal carcinoma (EC) cells (Garrido et al., 1995). Human EC cell lines like N-Tera2, and murine EC cell lines such as F9 and P19, like early mammalian embryonic cells, do not express class I MHC antigen (Morello et al., 1982). Undifferentiated EC cells in response to retinoic acid undergo differentiation and this induces expression of many genes including class I MHC genes (Nagata et al 1992). In general, these differences reflect basal tissue specific regulation of gene expression.

Expression of MHC I genes is regulated by a variety of nuclear factor which bind regulatory elements 5 to the coding sequences. Investigation of HLA-B7 genes showed the presence of cis-acting regulatory sequences between -75 to -660 , which are responsible for constitutive as well as IFN- $\gamma$ induced tissue-specific expression of this gene (Chamberlain et al., 1991). Similarly, enhancer $A$, and $B$ (Figure 1) regions present upstream of class I $\mathrm{MHC}$ coding sequence act as a negative element in F9 EC cells. After retinoic acid induced differentiation, this element appears to function as an enhancer for $\mathrm{MHC}$ I gene expression (Shirayoshi et al., 1987). Another negative regulatory element, has been demonstrated in the promoter of the miniature swine class I MHC gene, PD1 (Ehrlich et al., 1988). This element reduced the activity of both the heterologous simian virus 40 promoter and the homologous PD1 promoter. In vivo competition experiments indicated that the functions of the PD1 positive and negative elements are mediated by distinct cellular trans-acting factors called "enhancers" and "silencers" respectively (Weissman et al., 1991). This suggests that the expression of class I MHC genes is developmentally regulated and involves switching from negative to positive control (Miyazaki et al., 1986).

The class I regulatory element (CRE) is critical in determining the level of class I constitutive gene expression (Shirayoshi et al., 1987; Burke et al., 1989). In MHC $\mathrm{CRE}$, there are three discrete sequences (region I, II and III ) (Figure 1) that bind different nuclear protein factors. KBF1, NF- $\mathrm{KB}, \mathrm{H} 2 \mathrm{TF} 1$ are a few known factors that bind to region I (Kimura et al., 1986; Baldwin et al., 1988; Israel et al., 1989; Potter et al., 1993). Gel mobility shift assay showed that spleen and liver tissues showed

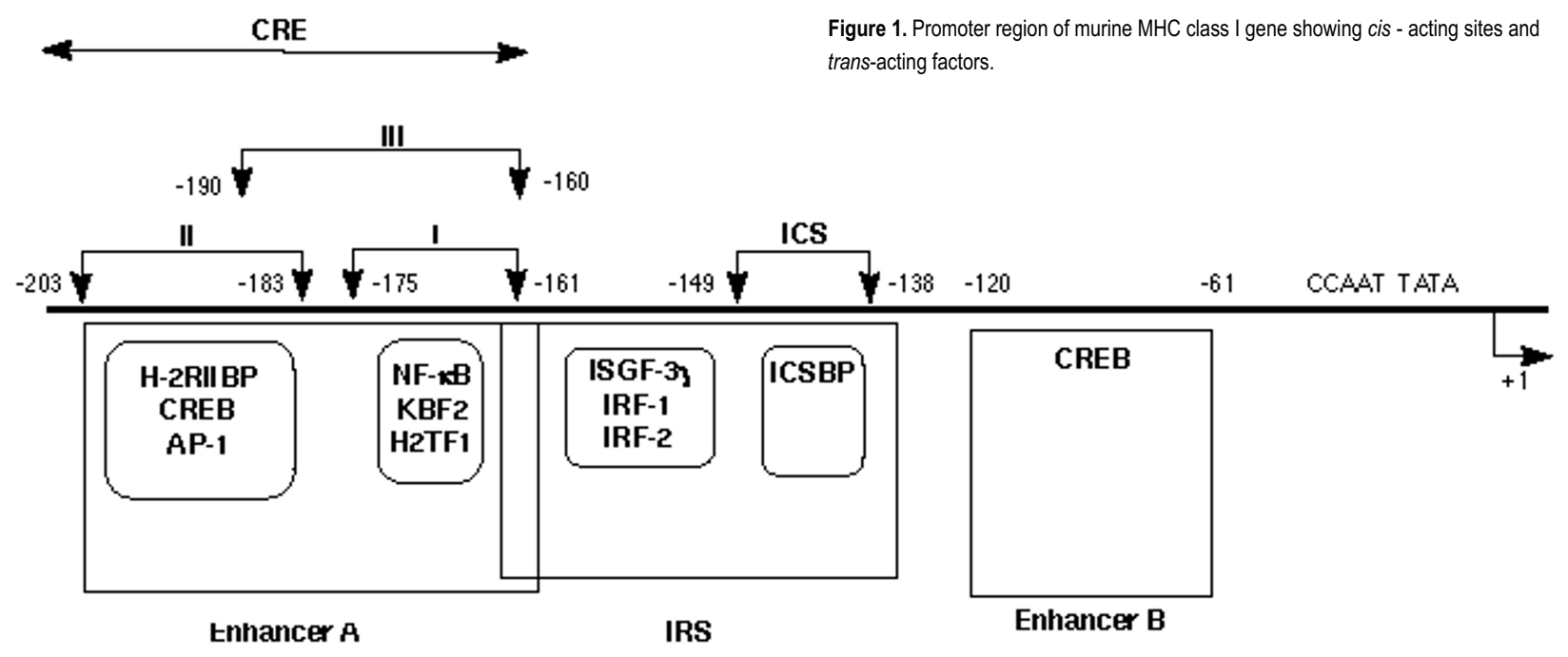


binding activity to region I but extract from brain did not show region I binding activity. Region II binding factors are namely AP1, CREB, H-2RIIBP (Roesler et al., 1988; Nagata et al., 1992). H-2RIIBP is a member of the nuclear hormone receptor superfamily and activates class I MHC expression in embryonal carcinoma cells in response to retinoic acid. Result of reporter gene CAT assay with mutant CRE constructs showed that the mutation that eliminated region I binding activity greatly impaired enhancer activity. Mutation that eliminated region II binding also caused a lesser but measurable effect. This indicated that both the region I and II are capable of enhancing class I MHC gene. Interestingly, fetal tissue that express very low levels of class I MHC, did not show any region I binding activity though it showed region II binding activity. Binding activity to region I becomes detectable during neonatal period when class I MHC expression sharply increases.

By in vivo footprinting of HLA-B7 transgene and the endogenous $\mathrm{H}-2 \mathrm{~Kb}$ gene it has been showen that the upstream regions of both the transgene and the endogenous gene were extensively occupied in spleen tissue and no occupancy was detected in brain tissue (Dey et al., 1992). Sites exhibiting in vivo protection corresponds to the cis-acting elements involed in regulation of class I MHC gene. This kind of negative regulation allows for rapid increases in transcription in response to immunomodulators e.g. IFN- $\gamma$ induces expression of class I MHC expression. As stated before, cells of central nervous system do not express class I antigens but showed induction of class I MHC expression in response to IFN$\gamma$ and TNF (Drew et al., 1993). Gel retardation assays show that these cytokines increased factor binding to distinct sites within regulatory elements of class I MHC gene and independently enhanced the expression of the gene. This suggests that the absence of class I MHC expression in the cells of central nervous system could be either due to absence of positive regulatory factor or due to presence of other factors ("silencer") which prevents the binding of the positive regulatory factor to the corresponding enhancer element in the upstream sequences of class I MHC genes.

\section{Mechanism of regulation of class I MHC gene by IFN- $\gamma$}

\section{IFN- $\gamma$ receptors}

Both type I (IFN- $\alpha$ and $\beta$ ) and type II (IFN- $\gamma$ ) IFNs influence $\mathrm{MHC}$ I expression, but they bind different cell surface receptors (Langer et al., 1988, Bazan et al., 1990). Both murine and human IFN- $\gamma$ receptors have been cloned and expressed (Auget et al., 1988; Gray et al., 1989; Hemmi et al., 1989; Kumar et al., 1989; Munru et al., 1989). IFN$\gamma$ receptors are $90 \mathrm{kDa}$ glycoproteins and are present on nearly all cell types. Based on nucleotide sequence data, mature human and murine IFN- $\gamma$ receptors consist of 472 and 451 amino acids, respectively and share $52 \%$ sequence homology. IFN- $\gamma$ receptor as well as $\mathrm{MHC}$ I genes are present on the human chromosome 6 . However, presence of chromosome 6 in somatic cell hybrids is insufficient to confer sensitivity to IFN- $\gamma$ as assayed by class I MHC induction. The presence of both human Chromosome 6 and 21 are required in the hybrid to generate a response to human IFN- $\gamma$ (Jung et al., 1987, Jung et al 1990, Hemmi et al., 1992). Similarly when murine IFN- $\gamma$ receptor on Chromosome 17 was expressed on human cells, it did not respond to murine IFN- $\gamma$. Only the presence of mouse Chromosome 16 exhibits complete concordance with MHC antigen expression in response to murine IFN- $\gamma$ (Hibino et al., 1991). This shows that both human and murine IFN- $\gamma$ receptors are themselves not sufficient to generate a biological response and they require an accessory factor(s), which is also responsible for the speciesspecificity of the receptor.

\section{IFN induced protein kinases}

Binding of IFNs with their respective receptors activates the Jak-Stat signal transduction pathway. Jak1, Jak2 and Tyk2 are the three members of the JAK (Janus Kinase) family of kinases which are activated in response to IFN. Jak1 (Wilks et al., 1991, Muller et al., 1993) and Jak2 (Silvennolnen et al., 1993; Wating et al., 1993) are associated with the IFN- $\gamma$ receptor and Jak1 and Tyk2 (Velazquez et al., 1992) are associated with type II IFN receptors. On binding of the ligand to its receptor, these kinases are activated, which in turn brings about activation of Stat (signal transducers and activators of transcription) family of proteins. Stats are the latent cytoplasmic proteins which are activated as a result of phosphorylation of their tyrosine residues.

Stat1 (both $a$ and b) and Stat2 are the two major signal transducers of Stat family involved in the activation of IFN inducible genes. After stimulation of cells by IFN- $\gamma$, a multiprotein transcription factor ISGF-3 (IFN stimulated gene factor-3) is quickly activated in cytoplasm (Kessler et al., 1990). This multiprotein complex is made up of four proteins, which are $91 \mathrm{kDa}$ (Stat 1a), $84 \mathrm{kDa}$ (Stat 1b), $113 \mathrm{kDa}$ (Stat 2) and $48 \mathrm{kDa}$ (ISGF3- $\gamma$ ) (Fu et al., 1992; Schindler et al., 1992). ISGF-3 complex translocates to the nucleus and binds the ISRE (IFN stimulated response element) present in the promoter region of class I MHC genes.

In case of IFN- $\gamma$, only the $91 \mathrm{kDa}$ (Stat 1a) is phosphorylated (Shuai et al 1992, Pearse et al., 1993). Phosphorylated Stat1 dimerizes, translocates to the nucleus and binds the IFN- $\gamma$ activation sites (GAS) in the promoter regions of IFN responsive genes, like class I MHC gene. GAS site was first identified in guanylate binding protein (GBP) gene (Lew et al., 1991). IFN- $\gamma$ causes transcrip-tional activation of GBP gene and a mutation in 

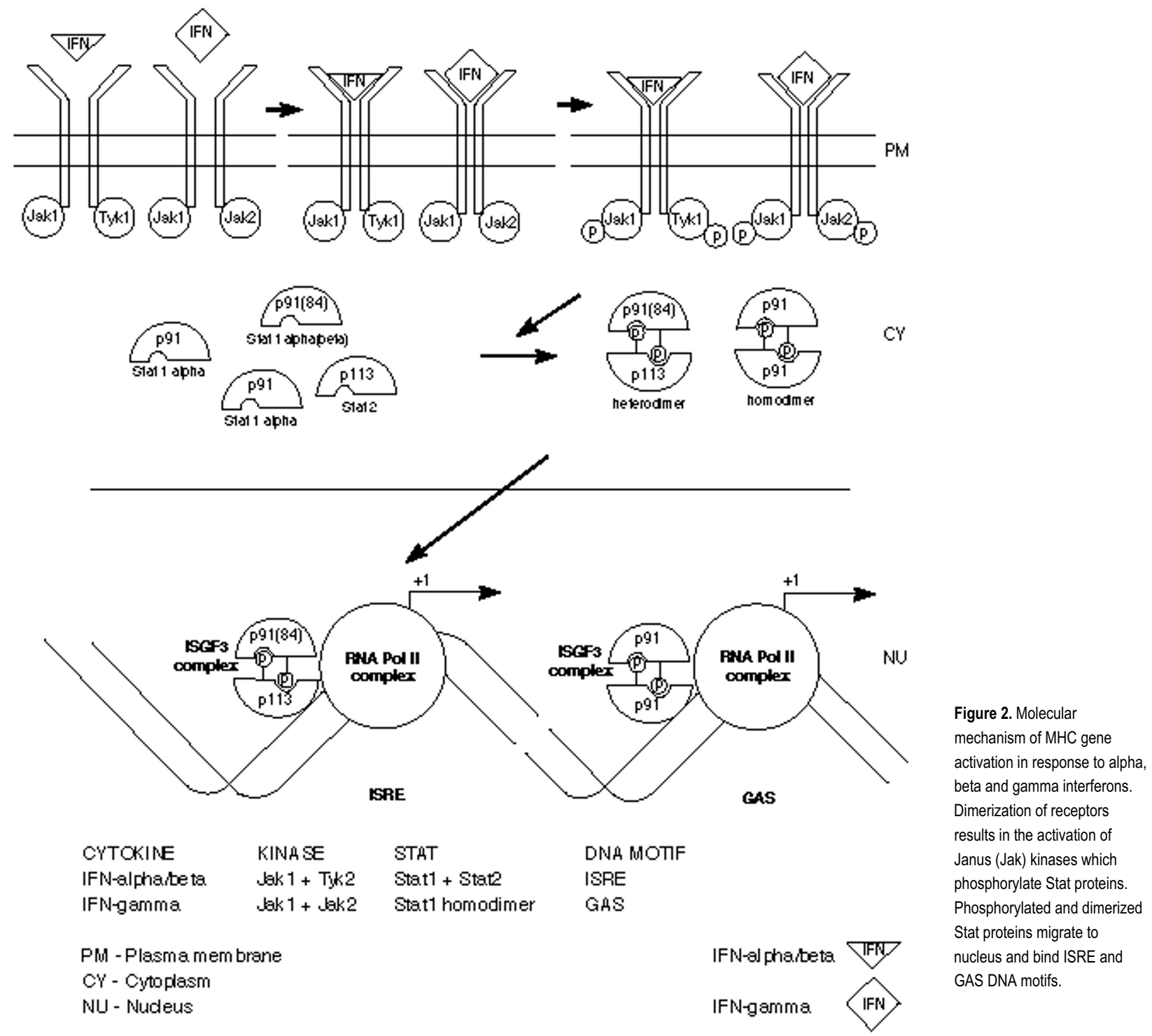

the GAS region blocks the activation.

Jak 1 is activated by both types of IFNs and is responsible for the phosphorylation of Stat 1 . Tyk 2 activated by type I IFN, is the kinase for Stat 2. Although, phosphorylation of Stat1a occurs in response to both IFN- $\gamma$ and IFN- $\alpha$, the specificity of the signalling is maintained because the Stat 2 is phosphorylated in response to IFN$\alpha$ alone and not in response to IFN- $\gamma$. At the cytoplasmic level therefore, Stat 1 homodimers and Stat 1-Stat 2 heterodimers determine the specificity of the generation of type II and type I IFN response respectivly.

\section{Cis-acting regulatory sequences}

Detailed analyses of the mouse MHC class I promoter has revealed several regions that are important for the

expression and regulation of this gene through specific DNA-binding proteins (Friedman et al., 1985, Israel et al., 1986, 1987, Shirayoshi et al., 1987, Sugita et al., 1987, David-Watine et al., 1990) (Figure 1, Table1). Mainly there are two enhancer like sequences, $A(-203$ to -161$)$ and $B$ (-120 to -61). Enhancer $A$ overlaps with an IFN response sequence, IRS (-165 to -139 , also called ISRE). Both enhancer sequences are conserved within the promoter regions of several genes coding class I MHC antigens. A strong homology has been found in the 5' promoter sequences of $\mathrm{H}-2 \mathrm{~Kb}, \mathrm{H}-2 \mathrm{Ld}, \mathrm{H}-2 \mathrm{Dd}$ as well as HLA-B7 genes indicating that regulation of class I MHC expression could be similar in both mouse and humans. Using deletion analysis of murine $\mathrm{H}-2 \mathrm{Dd}$ promoter, it was found that in general both enhancer $A$ and IRS regions are required 
for gene activation in response to type I IFNs, whereas IRS region appears to be sufficient for upregulating $\mathrm{MHC}$ I expression in response to type II IFN (Korber et al., 1987). However, there are differences in different experimental system. In L cells and BLK SV cells, the action of type I IFN require the presence of both enhancer $A$ and IRS but in BL5 cells, IRS region appears to be sufficient by itself (Korber et al., 1988). Enhancer $B$ is involved in tissue specific expressiom of class I MHC genes (Chamberlain et al., 1991). Another enhancer element, IFN consensus sequence ( -149 to 138 ) is present within the IRS and is found in a number of IFN-inducible genes (Shirayoshi et al., 1988, Driggers et al., 1990). There are some reports that regions located $3^{\prime}$ to the transcription start site are also involved in the regulation of class I MHC genes (Korber et al., 1987, Chamberlain et al., 1991). The 3' regulatory sequences could be involved in posttrans-criptional events such as an increase in RNA stability (Friedman et al., 1984) or in the rate of MHC class I mRNA translation. Region I of CRE, which overlaps with IRS, binds a TNF- $\alpha$ induced transcription factor belonging to $\mathrm{NF}-\mathrm{\kappa B} / \mathrm{rel}$ family, inducing MHC I expression (Drew et al 1993). Thus IFN- $\gamma$ and TNF- $\alpha$ induce transcription factors which bind to distinct cis-elements regulating $\mathrm{MHC}$ I gene expression. This explains the synergistic effect of IFN- $\gamma$ ang TNF- $\alpha$ on the expression of MHC class I antigens.

\section{Trans-acting regulating factors}

A number of transcription factors bind to the cis-acting elements described above, and regulate transcription of class I MHC gene. Amongst these, IFN regulatory factors (IRF) family of proteins plays an important role as they bind to the upstream regulatory sequences of the $\mathrm{MHC}$ । genes on treatment with IFNs. IRF-1 (37.3 kDa) and IRF-2 (39.5 kDa) are the first IRF members to be isolated (Miyamoto et al., 1988, Nelson et al., 1993). ISGF-3, which is a constituent of ISGF-3 and activated in response to only type I IFN, is also a member of the IRF family of transcription factors. Yet another important member of the IRF family is the IFN consensus binding protein (ICSBP) (Driggers et al., 1990), which is a $48 \mathrm{kDa}$ protein $45-47 \%$ sequence homologous to IRF-1 and IRF-2 over the $\mathrm{N}$-terminal 115 amino acid residues, which constitutes the DNA binding domain.

DNA sequence motifs in ISRE bind members of IRF family of transcription factors. Type I and type II IFN induced transcription factors bind overlapping yet distinct sites of ISRE. IRF-1 and IRF-2 bind the IRS (-165 to -139) region of the $\mathrm{MHC}$ I genes in response to IFN- $\gamma$ stimulation. IRF-1 activates the transcription if class I MHC genes, whereas IRF-2 represses IRF-1 mediated induction of class I MHC genes (Fugita et al., 1989, Harada et al 1990). ICSBP binds to ICS region present within IRS and represses the transcription of $\mathrm{MHC}$ I genes (Weisz et al., 1992, Kanno et al., 1993, Nelson et al., 1993). While both IRF-2 and ICSBP represses the expression of MHC I genes, they differ in their tissue distribution. ICSBP is predominantly present in the cells of lymphocyte and macrophage lineage (Driggers et al., 1990, Politis et al 1992, Nelson et al., 1996), whereas IRF-2 appears to be expressed more broadly (Harada et al., 1989, Harada et al., 1990). Furthermore, ICSBP expression is predominantly induced by IFN- $\gamma$ and not by type I IFN (Driggers et al., 1990, Politis et al., 1992) while IRF-1 and IRF-2 are generated in respons to both type I and type II IFN.

Constitutive expression of ICSBP in promonocytic cells and $B$ cells may be responsible for the low level of expression of class I MHC gene. Stimulation with IFN- $\gamma$ overides this negative regulation and result in the enhanced expression of class I MHC antigens. The attenuation of repression can be explained by two possible mechanisms. IFN- $\gamma$ may induce transcription activators which either displace ICSBP, or associates with ICSBP through a protein-protein interaction which now acts as an activator. Association of IRF family of proteins with each other has been demonstrated (Sharf et al., 1995). ICSBP was shown to tightly associate with IRF-2, conferring a cooperative DNA-binding activity upon both the protein. The association of ICSBP with IRF-1 is less stable and does not result in cooperative binding.

The picture that emerges from various studies is that the expression of class I MHC gene can be regulated through several pathways. Different transcription factors bind to different cis-acting sites depending on the kind of signal and the type of cell. Various trans-acting factors regulating class I MHC expression are induced by different types of IFN. How these different factors contribute to the fine tuning of class I MHC gene under physiological condition has yet to be fully understood.

\section{Acknowledgement}

Work in the authors' laboratory supported by a DBT grant. AR and NP got UGC fellowships.

\section{References}

Accolla, R. S., Adorini, L., Sartoris, S., Sinigaglia, F. and Guardiola, J. (1995) MHC: orchestrating the immune response. Immunol. Today 16: 8-11

Aguet, M., Dembie, Z. and Merlin, G. (1988) Molecular cloning and expression of human IFN- $\gamma$ receptor. Cell 55: 273-280

Alzona, M., Jack, H.-M., Fisher, R. I. and Ellis, T. M (1994) CD30 defines a subset of activated human $\mathrm{T}$ cells that produce IFN- $\gamma$ and IL- 5 and exhibit enhanced $B$ cell helper activity. J. Immunol. 153: 2861-2867

Au, W.-C., Moore, P. A., Lowther, W., Juang, Y.-T. and Pitha, P. M. (1995) Identification of a member of the IRF family that binds to the IFN stimulated response element an activates expression of IFN-induced genes. Proc. Natl. Acad. Sci. 92: 11657-11661 
Baldwin, A. S. and Sharp, P. A. (1988) Two transcription factors, NF-KB and H2TF1, interact with a single regulatory sequence in the class I MHC promoter. Proc. Natl. Acad. Sci. USA 85: 723-727

Batten, P., Yacoub, M. H. and Rose, M. L. (1996) Effect of human cytokines (IFN- $\gamma$, TNF$\alpha, \mathrm{IL}-1 \beta, \mathrm{IL}-4)$ on porcine endothelial cells: induction of MHC and adhesion molecules and functional significance of these changes. Immunology 87: 127-133

Bazan, J. F. (1990) Shared architecture of hormone binding domains of Type I and II IFN receptors. Cell 61: 753-754

Benham, A., Tulp, A. and Neefjes, J. (1995) Synthesis and assembly of MHC peptide complexes. Immunol. Today 16: 359-362

Burke, P. A., Hirschfeld, S., Shirayoshi, Y., Kasik, J. W., Hamada, K., Appella, Y. and Ozato, K. (1989) Developmental and tissue-specific expression of nuclear proteins that bind the regulatory element of the MHC class I gene. J. Exp. Med. 169: 1309-1321

Chamberlain, J. W, Vasavada, H. A., Ganguly, S. and Weissman, S. M. (1991) Identification of cis sequences controlling efficient position-independent tissue-specific expression of human MHC class I genes in transgenic mice. Mol. Cell. Biol. 11: 35643572

Chang, T. W., McKinney, S., Liu, V., Kung, P. C., Vilcek, J. and Le, J. (1984) Use of monoclonal antibodies as sensitive and specific probes for biologically active human gamma-interferon. Proc. Natl. Acad. Sci. USA 81: 5219-5222

Chang, C. H., Furue, M. and Tamaki, K. (1994) Selective regulation of ICAM-1 and major histocompatibility complex class I and II molecule expression on epidermal Langerhans cells by some of the cytokines released by keratinocytes and T cells. Eur. J. Immunol. 24: 2889-2895

David-Watine, B., Israel, A. and Kourilsky (1990) The regulation and expression of MHC class I genes. Immunol. Today 11: 286-292

Derynck, R., Leung, D. W., Gray, P. W. and Goeddel, D. V. (1982) Human interferongamma is encoded by a single class of mRNA. Nucl. Acids Res. 10: 3605-3615

Dey, A., Thornton, A. M., Lonergan, M., Weissman, S. M., Chamberlain, J. W. and Ozato, K. (1992) Occupancy of upstream regulatory sites in vivo coincides with MHC class I gene expression in mouse tissues. Mol. Cell. Biol. 12: 3590-3599

Drew, P. D., Lonergan, M., Goldstein, M. E., Lampson, L. A., Ozato, K. and McFarlin, D. E. (1993) Regulation of MHC class I and $\beta_{2}$-microglobulin gene expression in human neuronal cells. J. Immunol. 150: 3300-3310

Driggers, P. A., Ennist, D. L., Gleason, S. L., Mak, W.-H., Marks, M. S., Levi, B.-Z. Flanagan, J. R., Appella, E. and Ozato, K. (1990) An IFN- $\gamma$ regulated protein that binds the IFN-inducible enhancer element of MHC class I genes. Proc. Natl. Acad. Sci. USA 87: $3743-3747$

Ehrlich, R., Maguire, J. E. and Singer, D. (1988) Identification of negative and positive regulatory elements associated with class I MHC gene. Mol. Cell. Biol. 8: 695-703

Fehling, H. J., Swat, W., Laplace, C., Kuhn, R., Rajewsky, K., Muller, U. and Boehmer, H. (1994) MHC class I expression in mice lacking the proteasome subunit LMP-7. Science 265: 1234-1237

Fellous, M., Nir, U., Wallach, D., Merlin, G., Rubinstein, M. and Revel, M. (1992) Interferon-dependent induction of mRNA for the major histocompa-tibility antigens in human fibroblasts and lymphoblasts and lymphoblastoid cells. Proc. Natl. Acad. Sci. USA 79: $3082-3086$

Flavell, R. A., Allen, H., Burkly, L. C., Sherman, D. H., Waneck, G. L. and Widera, G (1986) Molecular biology of the H-2 histocompatibility complex. Science 233: 437-443

Fong, T. A. and Mosmaun, T. R. (1990) Alloreactive murine $\mathrm{CD} 8^{+}$T cell clones secrete the Th1 pattern of cytokines. J. Immunol. 144: 1744-1752

Fountoulakis, M., Zulauf, M., Lustig, A. and Garotta, G. (1992) Stoichiometry of interaction between interferon- $\gamma$ and its receptor. Eur. J. Biochem. 209: 781-787

Friedman, R. L., Manly, S. P., McMohan, M., Kerr, I. M. and Stark, G. R. (1984) Transcriptional and posttranscriptional regulation of IFN-induced gene expression in human cells. Cell 38: 745-755

Friedman, R. L. and Stark, G. R. (1985) IFN- $\alpha$ induced transcription of HLA and metallothionein genes containing homologous upstream sequences. Nature 314:637639

Fu, X.-Y., Schindler, C., Improta, T., Aebersold, R. and Darnell, J. E. Jr. (1992) The proteins of ISGF-3, the IFN- $\alpha$ induced transcriptional activator, define a gene family involved in signal transduction. Proc. Natl. Acad. Sci. USA 89: 7840-7843

Fujita, T., Miyamoto, M., Barsoumian, E. L. and Taniguchi, T. (1989) Induction of endogenous IFN- $\gamma$ and IFN- $\gamma$ genes by a regulatory trans-cription factor, IRF-1. Nature 337: $270-272$

Fultz, M. J., Barber, S. A., Dieffenbach, C. W. and Vogel, S. N. (1995) Induction of IFN$\gamma$ in macrophages by lipopolysaccharide. Int. Immunol. 5: 1383-1392

Garrido, F., Cabrera, T., Lopez-Nevot, M. A. and Ruiz-Cabello, F. (1995) HLA Class I antigens in tumors. Adv. Cancer Res. 67: 155-195

Gray, P. W. and Goeddel, D. V. (1983) Cloning and expression of murine interferon cDNA. Proc. Natl. Acad. Sci. USA 80: 5842-5846

Gray, P. W., Leong, S., Fennie, E. H., Farrar, M. A., Pingel, J. T., Fernandez-Luna, J. and Schreiber, R. D. (1989) Cloning and expression of the cDNA for the murine IFN- $\gamma$ receptor. Proc. Natl. Acad. Sci. USA 86: 8497-8501

Harada, H., Fujita, T., Miyamoto, M., Kimura, Y., Maruyama, M., Furia, A., Hiyata, T. and Taniguchi, T. (1989) Structurally similar but functionally distinct factors, IRF-1 and IRF2, binds to the same regulatory element of IFN and IFN inducible gene. Cell 58: 729739

Harada, H., Willison, K., Sakakibara, J., Miyamoto, M., Fujita, T. and Taniguchi, T. (1990) Absence of the type I IFN system in EC cells: Trans-criptional activator (IRF-1) and repressor (IRF-2) genes are developmentallyregulated. Cell 63: 303-312

Haridas, V. and Saxena, R. K. (1995) Changes in LAK susceptibility of tumor cells as their $\mathrm{MHC}$ I antigen expression levels regenerate after pH 3.0 treatment. Immunol. Lett. 44: 7-11

Haridas, V. and Saxena, R. K. (1995) Role of MHC I antigens in modulating the performance of murine tumor ells in cold target competition assays. Immunology 84: 8690

Hemmi, S., Peghini, P., Metzler, M., Merlin, G., Dembic, Z. and Aguet, M. (1989) Cloning of murine IFN- $\gamma$ receptor cDNA: Expression in human cells mediates high-affinity binding but is not sufficient to confer sensitivity to murine IFN- $\gamma$. Proc. Natl. Acad. Sci. USA 86: 9901-9905

Hemmi, S., Merlin, G. and Aguet, M. (1992) Functional characterization of a hybrid human-mouse IFN- $\gamma$ receptor: Evidence for species specific interaction of the extracellular receptor domain with a putative signal transducer. Proc. Natl. Acad. Sci. USA 89: 2737-2741

Hibino, Y., Mariano, T. M., Kumar, C. S., Kozak, C. A. and Pestka, S. (1991) Expression and reconstitution of a biologically active mouse IFN- $\gamma$ receptor in Hamster cells. J. Biol. Chem. 266: 6948-6951

Hochstenbach, F., David, V., Watkins, C. and Brenners, M. B. (1992) Endoplasmic reticulum resident protein of $90 \mathrm{kDa}$ associates with $\mathrm{T}$ - and $\mathrm{B}$-cell antigen receptors and MHC antigen during their assembly. Proc. Natl. Acad. Sci. USA 89: 4734-4738

Hui, H., Grosveld, F. and Festenstein, H. (1984) Rejection of transplantable AKR leukemia cells following MHC DNA-mediated cell transformation. Nature 311: 750-752

Inaba, K., Kitaura, M., Kato, T., Watanabe, Y., Kawade, Y. and Muramatsu, S. (1986) Contrasting effects of $\alpha / \beta$ and $\gamma$-interferons on expression of macrophage la antigens. J. Exp. Med. 163: 1030-1035

Israel, A., Kimura, A., Fournier, A., Fellous, M. and Kourilsky, P. (1986) IFN response sequence potentiates activity of an enhancer in the promoter region of a mouse $\mathrm{H}-2$ gene. Nature 322: 743-746

Israel, A., Kimura, A., Kieran, M., Yano, O., Kanellopoulos, J., Bail, O. L. and Kourilsky, 
P. (1987) A common positive trans-acting factor binds to enhancer sequences in the promoter of mouse $\mathrm{H}-2$ and $\beta_{2}$-microglobulin genes. Proc. Natl. Acad. Sci. USA 84: 2653-2657

Israel, A., Bail, O. L., Hatat, D., Piette, J., Kieran, M., Logeat, F., Wallach, D., Fellous, M. and Kourilsky, P. (1989) TNF stimulates expression of murine MHC class I genes by inducing an NF- KB like enhancer binding activity which displaces constitutive factor. EMBO J. 8: $3793-3800$

Jung, V., Rashidbaigi, A., Jones, C., Tischfield, J. A., Shows, B. T. and Pestka, S. (1987) Human chromosome 6 and 12 are required for sensi-tivity to human IFN- $\gamma$. Proc. Natl. Acad. Sci. USA 84: 4151-4155

Jung, V., Jones, C., Kumar, C. S., Stefanos, S., O'Connel, S. and Pestka, S. (1990) Expression and recognition of a biologically active human IFN- $\gamma$ receptor in hamster cells. J. Biol. Chem. 265: 1827-1830

Kanno, Y., Kozak, C. A., Schindler, C., Driggers, P. H., Ennist, D. L., Gleason, S. L., Darnell, J. E. Jr. and Ozato, K. (1993) The genomic structure of the murine ICSBP reveals the presence of the IFN- $\gamma$ responsive element, to which an ISGF3a subunit (or similar) molecule binds. Mol. Cell. Biol. 13: 3951-3963

Kelker, H. C., Yip, Y. K., Anderson, P. and Vilcek, J. (1983) Effects of glycosidase treatment on the physico-chemical properties and biological activity of human interferongamma. J. Biol. Chem. 258: 8010-8013

Kelker, H. C., Le, J., Rubin, B. Y., Yip, Y. K., Nagler, C. and Vilcek, J. (1984) Three molecular weight forms of natural human interferon-gamma revealed by immunoprecipitation with monoclonal antibody. J. Biol. Chem. 259: 4301-4304

Kessler, D. S., Veals, S. A., Fu, X. Y. and Levy, D. E. (1990) IFN- $\alpha$ regul-ates nuclear translocation and DNA binding affinity of ISGF3, a multimeric transcriptional activator. Genes. Develop. 4: 1753-1765

Kimura, A., Israel, A., Bail, O. L. and Kourilsky, P. (1986) Detailed analysis of the mouse $\mathrm{H}-2 \mathrm{~Kb}$ promoter: enhancer like sequence and their role in the regulation of class I MHC expression. Cell 44: 261-272

King, D. P. and Jones, P. P. (1983) Induction of la and H-2 antigens on a macrophage cell line by immune interferon. J. Immunol. 131: 315-318

Korber, B., Hood, L. and Stroynowski, I. (1987) Regulation of murine class I gene by IFN is controlled by regions located both $5^{\prime}$ and $3^{\prime}$ to the transcription initiation site. Proc. Natl. Acad. Sci. USA 84: 3380-3384

Korber, B., Mermod, N., Hood, L. and Stroynowski, I. (1988) Regulation of gene expression by IFNs: Control of H-2 promoter responses; Science 239: 1302-1306

Kovacsovics-Bankowski, M. and Rock, K. L. (1994) Presentation of exogenous antigens by macrophages: analysis of $\mathrm{MHC}$ class I and II presentation and regulation by cytokines. Eur. J. Immunol. 24: 2421-2428

Kumar, C. S., Muthukumaran, G., Frost, L. J., Noe, M., Ahu, Y. H., Mariano, T. M. and Pestka, S. (1989) Molecular characterization of the murine IFN- $\gamma$ receptor cDNA. J. Biol. Chem. 264: 17939-17946

Langer, J. A. and Pestka, S. (1988) Interferon receptors. Immunol. Today 16: 393-400

Lehner, P. J. and Cresswell, P. (1996) Processing and delivery of peptides presented by MHC class I molecules. Curr. Opin. Immunol. 8: 59-67

Lew, D. J., Decker, T., Strehlow, I. and Darnell, J. E. (1991) Overlapping elements in the guanylate-binding protein gene promoter mediate transcriptional induction by IFN- $\alpha$ and $\gamma$. Mol. Cell. Biol. 11: 182-191

Li, C. B., Gray, P. W., Lin, P.-F., McGrath, K. M., Ruddle, F. H. and Ruddle, N. H. (1987) Cloning and expression of murine lymphotoxin cDNA. J. Immunol. 138: 4496-4501

Miyamoto, M., Fijita, T., Kimura, Y., Maruyama, M., Harada, H., Sudo, Y. Miyata, T. and Taniguchi, T. (1988) Regulated expression of a gene encoding a nuclear factor, IRF-1, that specifically bind to IFN- $\beta$ gene regulatory element. Cell 54: 903-913

Miyazaki, J. E., Appella, E. and Ozato, K. (1986) Negative regulation of the MHC class I gene in undifferentiated embryonal carcinoma cells. Proc. Natl. Acad. Sci. USA 83:
$9537-9541$

Momburg, F., Roelse, J., Howard, J. C., Butcher, G. W., Hammerling, G. J. and Neefjes, J. J. (1994) Selectivity of MHC-encoded peptide trans-porters from human, mouse and rat. Nature $367: 648-651$

Monaco, J. J., Cho, S. and Attaya, M. (1990) Transport protein genes in the murine MHC: Possible implications for antigen processing. Science 250: 1723-1726

Morello, D., Daniel., Baldacci, P., Cayre, Y., Gachelin, G. and Kourilsky, (1982) Absence of significant $\mathrm{H}-2$ and $\beta_{2}$-microglobulin mRNA expression by embryonal carcinoma cells. Nature 296: 260-262

Mulkerrin, M. G. and Wetzel, R. (1989) pH dependence of the reversible and irreversible thermal denaturation of gamma interferons. Biochemistry 28: 6556-6561

Muller, M., Briscoe, J., Laxton, C., Guschin, D., Ziemiecki, A., Silvennolnen, O., Harper, A. G., Barbier, B. A., Witthuhn, B. A., Schindler, C., Pelligrini, S., Wilks, A. F., Ihle, J. N., Stark, G. R. and Kerr, I. M. (1993) The protein tyrosine kinase JAK1 complements defects in interferon- $\alpha / \beta$ and $\gamma$ signal transduction. Nature 366: 129-131

Munro, S. and Maniatis, T. (1989) Expression and cloning of the murine IFN- $\gamma$ receptor cDNA. Proc. Natl. Acad. Sci. USA 86: 9248-9252

Nagata, K., Izumi, T., Kitagawa, T. and Yoshida, N. (1987) Oligomeric structure of recombinant human and murine immune interferons by means of sedimentation equilibrium. J. Interferon Res. 7: 313-320

Nagata, T., Segars, J. H., Levi, B.-Z. and Ozato, K. (1992) Retinoic acid-dependent transactivation of MHC class I promoters by the nuclear hormone receptor H-2RIIBP in undifferentiated embryonal carcinoma cells. Proc. Natl. Acad. Sci. USA 89: 937-941

Nedwin, G., Naylor, S. L., Sakaguchi, A. Y., Smith, D., Nedwin, G. E., Pennica, D., Goedell, D. V. and Gray, P. W. (1985) Human lymphotoxin and tumor necrosis factor genes: structure, homology and chromosome location. Nucleic Acids Res. 13: 63616372

Neefjes, J. J., Momberg, F. and Hammerling, G. J. (1993) Selective and ATPdependent translocation of peptides by the MHC encoded transporter. Science 261: 769771

Nelson, N., Marks, M. S., Driggers, P. H. and Ozato, K. (1993) ICSBP, a member of the IFN regulatory factor family, Suppresses IFN-induced gene transcription. Mol. Cell. Biol. 13: 588-599

Nelson, N., Kanno, Y., Hong, C., Coniursi, C., Fujita, T., Fowlkes, B. J., O'Conneil, E., Hu-Li, J., Paul, W. E., Jankovic, D., Sher, A. F., Coligan, J. E., Thornton, A., Apella, E., Yang, Y. and Ozato, K. (1996) Expression of IFN regulatory factor family proteins in lymphocytes. J. Immunol. 156: 3711-3720

Old, L. J. (1985) Tumor Necrosis Factor (TNF). Science 230: 630-632

Pace, J. L., Russell, S. W., LeBlanc, P. A. and Murasko, D. M. (1985) Comparative effects of various classes of mouse interferons on macrophage activation for tumor cell killing. J. Immunol. 134: 977-981

Paul, N. L. and Ruddle, N. (1988) Lymphotoxin. Annu. Rev. Immunol. 6: 407-438

Pearse, R. N., Feinman, R., Shuai, K. Darnell, J. E. Jr. and Ravetch, J. V, (1993) IFN- $\gamma$ induced transcription of the high-affinity $F c$ receptor for IgG requires assembly of a complex that includes the $91-\mathrm{kD}$ a subunit of transcription factor ISGF-3. Proc. Natl. Acad. Sci. USA 90: 4314-4318

Pennica, D., Hayflick, J. S., Bringman, T. S., Palladino, M. A. and Goeddel, D. V. (1985) Cloning and expression in Escherichia coli of the cDNA for murine tumor necrosis factor. Proc. Natl. Acad. Sci. USA 82: 6060-6064

Pfizenmaier, K., Scheurich, P., Schluter, C. and Kronke, M. (1987) Tumor necrosis factor enhances HLA-A, B, C and HLA-DR gene expression in human tumor cells. J. Immunol. 138: 975-980

Ploegh, H., Orr, M. T. and Strominger, J. L. (1981) Major histocompatibility antigens: The human (HLA-A, -B, -C) and murine (H-2K, H-2D) class I molecules. Cell 24 287-299 
Pober, J. S., Lapierre, L. A., Stolpen, A. H., Brock, T. A., Springer, T. A., Fiers, W., Bevilacqua, M. P., Mendrick, D. L. and Gimbrone, M. A. (1987) Activation of cultured human endothelial cells by recombinant lymphotoxin: Comparison with tumor necrosis factor and interleukin 1 species. J. Immunol. 138: 3319-3324

Politis, A. D., Sivo, J., Driggers, P. H., Ozato, K. and Vogel, S. N. (1992) Modulation of ICSBP protein mRNA in murine peritoneal macrophages. J. Immunol. 148: 801-807

Potter, D. A., Larson, C. J., Eckes, P., Schmid, R. M., Nobel, G. J., Verdive, G. L. and Sharp, P. A. (1993) Purification of the MHC class I transcription factor H2TF1. J. Biol. Chem. 268: 18882-18890

Proffitt, J. L., Sharma, E. and Blair, G. E. (1994) Adenovirus 12 mediated down regulation of the MHC class I promoter: Identification of a negative regulatory element responsive to Ad 12 EIA. Nucleic Acid Res. 22: 4779-4788

Puri, N., Raval, A. and Saxena, R. K. (1997) Species specificity of a novel factor which augments the expression of MHC class I antigens on tumor cell lines. Exp. Mol. Med 29: $129-132$

Puri, N. and Saxena, R. K. (1997) Partial purification and characterization of a novel murine factor that augments the expression of class I MHC antigens on tumor cells. (in preparation)

Raval, A. (1998) Purification of a novel human cytokine which augments the expression of class I MHC antigens on tumor cells, and comparison of its mechanism of action with gamma interferon. Ph.D. Thesis, School of Life Sciences, Jawaharlal Nehru University, New Delhi

Raval, A., Puri, N. and Saxena, R. K. (1997) Generation of human class I major histocompatibility complex activating factor (MHC-AF) in serum free medium and its partial characterization. J. Biosciences 22: 59-68

Rock, K. L., Gramm, C., Rothstein, L., Clark, K., Stein, R., Dick, L., Hwang, D. and Goldberg, A. L. (1994) Inhibitors of the proteasome block the de-gradation of most cell proteins and the generation of peptides presented on MHC class I molecule. Cell 78 : 761-771

Roesler, W. J., Vandenbark, G. R. and Hanson, R. W. (1988) Cyclic AMP and induction of eukaryotic gene transcription. J. Biol. Chem. 263: 9063-9066

Rosa, F. and Fellous, M. (1984) The effect of gamma-interferon on MHC antigens. Immunol. Today 9: 261-262

Rosa, F. M., Cochet, M. M. and Fellous, M. (1986) Interferon and major histocompatibility genes: A model to analyze eukaryotic gene regulation. In Interferon 7, (Gresser, I., ed.), p. 47, Academic Press, London

Sadasivan, B., Lehner, P. J., Ortmann, B., Spies, T. and Cresswell, P. (1996) Role of calreticulin and a novel glycoprotein tapasin, in the interaction of MHC class I molecule. Immunity 5: 103-114

Sarin, A., Saxena, Q. B., Herberman, R. B. and Saxena, R. K. (1995) Enhanced MHC I antigen expression on tumor target cells is inversely correlated to lysis by allogenic but not by xenogenic NK cells. J. Biosciences 20: 515-523

Saxena, R. K. (1987) A spleen cell derived factor imparts resistance to NK cell mediated lysis in a mouse lymphoma cell line. Immunol. Lett. 15: 105-108

Saxena, R. K., Saxena, Q. B. and Adler, W. H. (1988) Properties and characterization of a rat spleen cell derived factor which induces resistance to NK cell lysis in YAC lymphoma cells. J. Immunol. 141: 1782-1787

Saxena, R. K., Saxena, Q. B., Sarin, A. and Herberman, R. B. (1992) Natural KillerResistance Inducing Factor (NK-RIF): In NK Cell mediated cytotoxicity: Receptors, signaling and mechanisms (Lotzovz, E. and Herberman, R. B., eds.), p. 381, CRC Press

Saxena, R. K., Saxena, Q. B., Whiteside, T. L., Goldfarb, R. H. and Herberman, R. B. (1996) Partial purification and characterization of a novel human factor that augments the expression of class I MHC antigens on tumor cells. J. Biosciences 21: 13-25

Saxena, R. K., Haridas, V. and Sarin, A. (1995) Regulation of NK suscep-tibility by target cell class I MHC molecules. Indian J. Biochemistry and Biophysics 32: 179-185

Scheurich, P., Kronke, M., Schluter, C., Ucer, U. and Pfizenmaier, K. (1986) Noncytocidal mechanisms of action of tumor necrosis factor- $\alpha$ on human tumor cells: Enhancement of HLA gene expression synergistic with interferon- $\gamma$. Immunobiol. 172: 291

Schindler, C., Fu, X.-Y., Improta, T., Aebersold, R. and Darnell, J. E. Jr. (1992) Proteins of transcription factor ISGF-3:One gene encodes 91- and 84-kDa ISGF-3 proteins that are activated by IFN- $\alpha$. Proc. Natl. Acad. Sci. USA 89: 7836-7839

Schumacher, T. N. M., Kantesaria, D. V., Heemels, M.-T., Ashton-Rickardt, P. G., Shepherd, J. C., Fruh, K., Yang, Y., Peterson, P. A., Tonegawa, S. and Ploegh, H. L. (1994) Peptide length and sequence specificity of the mouse TAP1/TAP2 translocator. J. Exp. Med. 179: 533-540

Sharf, R., Azriel, A., Lejbkowicz, F., Winograd, S. S., Ehrlich, R. and Levi, B.-Z. (1995) Functional domain analysis of ICSBP and its association with IFN regulatory factors. $J$. Biol. Chem. 270: 13063-13069

Shirayoshi, Y., Miyazaki, J.-I., Burke, P. A., Hamada, K., Appella, E. and Ozato, K. (1987) Binding of multiple nuclear factors to the 5 ' upstream regulatory element of the murine MHC. Mol. Cell. Biol. 7: 4542-4548

Shirayoshi, Y., Burke, P. A., Appella, E. and Ozato, K. (1988) IFN-induced transcription of a MHC class I gene accompanies binding of inducible nuclear factors to the interferon consensus sequence. Proc. Natl. Acad. Sci. USA 85: 5884-5888

Shuai, K., Schindler, C., Prezioso, V. R. and Darnell, J. E. Jr. (1992) Activation of transcription by IFN- $\gamma$ : Tyrosine phosphorylation of a $91-\mathrm{kDa}$ DNA binding protein. Science 258: 1808-1812

Silvennolnen, O., Witthuhn, B. A., Quelle, F. W. and Cleveland, J. L. (1993) Structure of the murine JAK2 protein kinase and its role in IL-3 signal transduction. Proc. Natl. Acad. Sci. USA 90: 8429-8433

Spies, Y., Bresnahan, S., Bahram, S., Arnold, D., Blanck, G., Mellins, E., Pious, D. and DeMars, R. (1990) A gene in the MHC class II region containing the class I antigen presentation pathway. Nature 348: 744-747

Sugita, K., Miyazaki, J.-I., Appella, E. and Ozato, K. (1987) IFN increase transcription of a MHC class I via a 5' IFN consensus sequence. Mol. Cell. Biol. 7: 2625-2630

Trinchieri, G. and Perussia, B. (1985) Immune interferon: a pleiotropic lymphokine with multiple effects. Immunol. Today 6: 131-136

Van, K. L., Ashton-Rickardt, P. G., Eicheiberger, M., Gaczynska, M., Nagashima, K., Rock, K. L., Goldberg, A. L., Doherty, P. C. and Tongawa, S. (1994) Altered peptidases and viral-specific T cell response in LPM-2 mutant mice. Immunity 1: 533-541

Velazquez, L., Fellous, M., Stark, G. R. and Pellegrini, S. (1992) A protein tyrosine kinase in IFN $\alpha / \beta$ signaling pathway. Cell 70: 313-322

Wallich, R., Bulbuc, N., Hammerling, G. J., Katzav, S., Segal, S. and Feldman, M. (1985) Abrogation of metastatic properties of tumor cells by de novo expression of $\mathrm{H}$ 2K antigens following H-2 gene transfection. Nature 315: 301-305

Wang, P., Raynoschek, C., Svensson, K. and Ljunggren, (1996) Binding of H-2Kbspecific peptides to TAP and MHC class I in microsomes from wild type, TAP1, and $\beta_{2-}$ microglobulin mutant mice. J. Biol. Chem. 271: 24830-24835

Wating, D., Guschin, D., Muller, M., Silvennolnen, O., Witthuhn, B. A., Quelle, F. W., Rogers, N. C., Schindler, C., Stark, G. R., Ihle, J. N. and Kerr, I. M. (1993) Complementation by the tyrosine kinase JAK2 of a mutant cell line defective in the IFN$\gamma$ signal transduction pathway. Nature 366: 166-170

Weissman, J. D. and Singer, D. S. (1991) A complex regulatory DNA element associated a MHC class I gene consists of both a silencer and an enhancer. Mol. Cell. Biol. 11: 4217-4227

Weisz, A., Marx, P., Sharf, R., Appellas, E., Driggers, P. H., Ozato, K. and Levi, B.-Z. (1992) Human ICSBP is a negative regulator of enhancer elements common to IFNinducible genes. J. Biol. Chem. 267: 25589-25596

Wilks, A. F., Harper, A. G., Kurban, R. R., Ralph, S. J., Zurcher, G. and Ziemiecki, A. 
(1991) Two novel protein-tyrosine kinase, each with a second phosphotransferase related catalytic domain, define a new class of protein kinase. Mol. Cell. Biol. 11: 20572065

Williams, A. F. and Barclay, A. N. (1988) The immunoglobulin superfamily. Domains for cell recognition. Annu. Rev. Immunol. 6: 381-405

Zinkernagel, R. M. and Doherty, P. C. (1979) MHC-restricted cytotoxic T cells: studies on the biological role of polymorphic major transplantation antigens determining T-cell restriction specificity, function and responsiveness. Adv. Immunol. 27: 51-177 